\title{
IMPACT OF OWNERSHIP CONCENTRATION, INSTITUTIONAL OWNERSHIP AND EARNINGS MANAGEMENT ON STOCK MARKET LIQUIDITY
}

\author{
Ahmed Imran Hunjra ${ }^{*}$, Uzma Perveen ${ }^{* * *}$, Leon $\mathrm{Li}^{* * * * *}$, \\ Muhammad Irfan Chani ${ }^{* * * *}$, Rashid Mehmood \\ * Corresponding author, University Institute of Management Sciences, PMAS-Arid Agriculture University Rawalpindi, Pakistan \\ Contact details: PMAS-Arid Agriculture University Rawalpindi, Shamsabad, Muree Road Rawalpindi, Pakistan \\ ** University Institute of Management Sciences, PMAS-Arid Agriculture University Rawalpindi, Pakistan \\ *** School of Accounting, Finance and Economics, The University of Waikato, New Zealand \\ **** Department of Management Sciences, COMSATS University Islamabad, Vehari Campus, Pakistan
}

OPEN ACCESS

How to cite this paper: Hunjra, A. I., Perveen, U., Li, L., Chani, M. I., \& Mehmood, R. (2020). Impact of ownership concentration, institutional ownership and earnings management on stock market liquidity. Corporate Ownership \& Control, 17(2), 77-87.

http://doi.org/10.22495/cocvl 7i2art7

Copyright $@ 2020$ The Authors

This work is licensed under a Creative Commons Attribution 4.0 International License (CC BY 4.0).

https://creativecommons.org/licenses/by/ 4.0/

ISSN Online: 1810-3057

ISSN Print: 1727-9232

Received: 08.12.2019

Accepted: 22.01.2020
Abstract

Ownership structure plays a vital role in stock market liquidity. We analyze the impact of ownership concentration, institutional ownership and earnings management on stock market liquidity. We select 114 firms from manufacturing sector of Pakistan, India, Australia and Singapore. We extract data from DataStream from 2010 to 2018 of selected countries. We apply Generalized Method of Moments (GMM) to analyze the data. We find that ownership concentration, institutional ownership and earnings management significantly affect the stock market liquidity.

Keywords: Ownership Concentration, Institutional Ownership, Earnings Management, Stock Market Liquidity, Emerging Economies

Authors' individual contribution: Conceptualization - A.I.H. and R.M.; Writing - U.P., M.I.C., and R.M.; Methodology - A.I.H., M.I.C., and L.L.; Supervision - A.I.H.; Formal Analysis - L.L., A.I.H., and R.M.

JEL Classification: G14, G32, G34, M48 DOI: $10.22495 / \operatorname{cocvl7i2art7}$

\section{INTRODUCTION}

Stock market liquidity has become an interesting area of research, and many studies have been conducted in different aspects. In developed and emerging markets, the liquidity of the stock market is essential because a liquid market allows the efficient allocation of financial resources, as efficient allocation is the prerequisite for the growth and development of the financial market. The greater the liquidity of a financial market is, the greater the value of a firm is because a liquid market tends to reduce the cost of capital (Wang, 2013). A growing body of the literature suggests that liquidity foretells the stock returns at the firm and stock market levels (Brennan, Chordia, \& Subrahmanyam, 1998). Most of the studies explore the relationship between corporate governance and stock market liquidity in developed economies, using data from the New York Stock Exchange. While, developed countries, other than the United States of America (USA), and emerging economies are relatively less explored. The literature based on South Asian countries is very scarce. Therefore, there is a need to explore how ownership concentration, institutional ownership and earnings management lead to stock market liquidity in the emerging economies and nonUSA developed nations. Emerging markets are facing stock market liquidity issues as information asymmetry is high when compared to markets in developed countries. In emerging markets, information asymmetry exists between informed and uninformed stockholders and this reduces stock market liquidity (Rubin, 2007). 
In emerging economies, high levels of ownership concentration result in creating the type II agency problem. However, in this situation, major stockholders are at the advantage of getting access to more private and valuable information about the firm's future earnings when compared to the minority stockholders. Therefore, in emerging economies, ownership concentration negatively affects the stock market liquidity (Lev, 1988; BarYosef \& Prencipe, 2013). In addition, the business environment of Asian countries is different from that of the developed countries. Asian companies have a heterogeneous business environment, and they have unique ownership concentration (Connelly, Limpaphayom, \& Nagarajan, 2012).

We analyze the influence of ownership concentration, institutional ownership and earnings management on stock market liquidity in two developed countries (Australia and Singapore) and two emerging economies (Pakistan and India). The growth in the economy and financial market of Singapore has motivated us to analyze the stock market performance of Singapore. The importance of the economy of Singapore can be drawn from the fact that in 2013, the International Monetary Fund (IMF) considered Singapore to be the only country in Association of Southeast Asian Nations (ASEAN) as a developed nation (Goh, Annuar, \& Zariyawati, 2014). Thus, the investors in Singapore have more concerns about the risk of their portfolio and they are keen for a wider market to diversify their risk. In addition, the reason for selecting Australia is that the Australian stock market is referred to one of the most established markets throughout the world. We emphasize the ownership concentration because firms and management are the same in family and concentrated ownership and they face different rules as compared to non-concentrated and nonfamily ownership firms in decision making and it helps to minimize business risk (Saleh, Halili, Zeitun, \& Salim, 2017). Family-owned firms are operating for a longer time period than non-family owned firms and they have lasted for many years throughout the world and in Australia. Family businesses are found to be older than nonfamily businesses and they have survived over centuries worldwide and in Australia (Block, 2011). In Pakistan and India, corporate governance practices play an important part while managing matters of the firms. According to Ullah, Afgan, Hashim, and Khan (2016), corporate governance plays an important role towards the growth of Pakistan's economy. Pakistan represents an emerging economy as most of the firms in Pakistan have family ownership or concentrated ownership. In such situation, management does not play an active part in operating business matters (Yasser \& Mamun, 2017). According to Javid and Iqbal (2008), firms in Pakistan have concentrated and family-oriented ownership because of the inefficient legal system. Further, firms in India are also based on family ownership.

Corporate governance has grabbed the attention of regulatory bodies after the disclosure of fraudulent practices followed by the world's renowned companies such as Enron, Xerox, and WorldCom. Claessens and Yurtoglu (2013) describe that an effective system of governance is useful for companies with access to finance, better financial output, and desired output for stakeholders. Corporate governance system helps companies to overcome agency issue as institutional and individual investors are keen to invest in those companies which are having good governance practices (Mehmood, Hunjra, \& Chani, 2019). The manipulated financial reports of these companies affected the world economy adversely, and many users of financial statements lose confidence in the financial reporting process (Yoon, Miller, \& Jiraporn, 2006). After the earnings management scandal, the US Securities and Exchange Commission investigate the matter and find that the bankruptcy of Enron is due to earnings management practices. Such events draw the attention of researchers and legislative bodies to examine earnings management practices (Mostafa, 2017). The implementation of corporate governance policies is relatively weak in the emerging markets, and result in reducing the liquidity of stock markets. Further, the comparison of developing countries with developed countries helps us to obtain insights about possible future strategies for emerging economies.

This paper is structured into five sections. Section 2 reviews the relevant literature and develops hypotheses. Section 3 explains the methodology. Section 4 presents and discusses the empirical results. Section 5 summarizes and concludes the paper.

\section{LITERATURE REVIEW}

Ownership concentration can cause an agency problem between informed stockholders and uninformed stockholders. Informed stockholders have an advantage of more insider information. They can use insider information to protect their interest by using the corporate resources for their gain thereby infringing the rights of minority stockholders. Agency issues arising from the conflict of interest between minority stockholders and majority stockholders, in turn, lead to agency cost. Agency cost can affect the stock market valuation in the countries where governance mechanism is weak (La Porta, Lopez-de-Silanes, Shleifer, \& Vishny, 2002). When ownership is concentrated, then majority stockholders have the opportunity and power to influence, by their decisions and actions, the interest of minority stockholders. The majority stockholders strain to form coalitions in order to gain more control of the firm because in this way they can get many personal benefits (Shleifer \& Vishny, 1997; Desoky \& Mousa, 2013). Further, when controlling stockholders rule over an organization, they can monitor and direct the actions of the managers and in favor of the organization, thus to mitigate the agency problem between stockholders and managers (Grossman \& Hart, 1988).

In emerging economies, the agency problem between minority and majority stockholders is more critical than the agency problem between managers and stockholders (Lei, Lin, \& Wei, 2013). Therefore, for emerging markets, ownership dispersion is essential for the stock market liquidity because dispersed ownership tends to minimize the information asymmetry and will ultimately give rise to the number of market participants for the stock of a company, therefore, stock market liquidity will increase. The more diffused ownership, the higher will be the stock market liquidity as dispersed ownership leads to more potential market participants for the stock of a firm. Conversely, some studies also find the inverse impact of 
ownership concentration on stock market liquidity (Yosra \& Sioud, 2011; Yaghoobnezhad, Roodposhti, \& Zabihi, 2011). Further, concentrated ownership restricts the stocks of a company to be traded among only a few market players which in turn reduces the stock market liquidity (Brockman \& Oslen, 2013). Leano and Pedraza (2018), Sharif, Bino, and Tayeh (2015) find an inverse relationship between ownership concentration and stock liquidity. Therefore, we develop the first hypothesis:

H1: Ownership Concentration has a significant impact on stock market liquidity.

Globally, institutional owners are considered the most significant market players for stock market liquidity. Institutional investors are motivated to get a financial returns as well as social returns (Dyck, 2019). The importance of institutional investors is increasing in the developed economies, and it is also growing rapidly in the emerging economies as well (Khorana, Servaes, \& Tufano, 2005). The ability of institutional investors to affect business decisions depends on the size of the stockholdings (Maug, 1998). If stockholdings of institutional investors are large, stocks will be less marketable and will be retained longer. Due to this, institutional stockholders have the motivation to monitor the activities of managers to avoid agency conflict and the overall performance of the stock. Whereas, if stock holdings are small and firm performance is low these investors can easily cash out their investment. Therefore, they have weaker incentives to monitor market performance. Some studies indicate that institutional investor's inclination towards maintaining liquidity of stockholdings and gaining short-term profits overrun the benefits of monitoring (Bhide, 1994; Coffee, 1991; Maug, 1998). Almutairi (2013) examines the impact of institutional ownership and corporate debt on audit quality and finds that the presence of institutional stockholders improves the quality of the audit. When audit quality is improved, it will discourage fraudulent earnings management practices, and as a result, stock market liquidity will improve. Dang (2018) documents a positive influence of institutional ownership on stock liquidity. Ali and Hashmi (2018) also signify that stock liquidity is led by institutions investment. The literature explains that institutional investors play a vital role to increase stock market liquidity. Institutions are motivated by both financial and social returns. Hence, we develop the second hypothesis as:

H2: Institutional Ownership has a significan impact on stock market liquidity.

Earnings management can either improve the firm's performance or liquidity depending on whether earnings management is opportunistic or discretionary. When managers intentionally manage the earnings with the aim to enhance the information content of their company's performance for the benefit of traders, this increases the disclosure and quality of financial reporting of a firm to give a better view of the firm's performance to the market traders (Jiraporn, Miller, Yoon, \& Kim, 2008). On the other hand, managers may manipulate the earnings to disclose less information about the financial performance of the firm to the stakeholders with the intention to mask the poor financial performance; this is called opportunistic earnings management.
Opportunistic earnings management reduces the firm's information disclosure as well as the quality of a firm's financial reporting. Moreover, it decreases the transparency of the firm's information disclosure. Managers use this type of earnings management to pursue their interests by misleading the investors (Desai, Miller, Yoon, \& Kim, 2004). Earnings quality is considered to be a significant source of information asymmetry which affects the stock market liquidity. A high level of earnings management tends to increase information asymmetry among informed and uninformed investors. The credibility of the financial reports is affected and uncertainty about the firm's future cash flows increases, and thus earnings management may reduce stock liquidity (Bar-Yosef \& Prencipe, 2013). Earnings management practices result in unethical accounting practices. As a result, finance providers of the firms engage themselves in widening the bid-ask spreads to protect themselves from penalties. Therefore, firms with higher earnings management tend to suffer from low lower levels of stock liquidity (Chung, Sheu, \& Wang, 2009). Ajina and Habib (2017) exhibit a negative relationship between earnings management and stock liquidity. In light of this, we develop the third hypothesis:

H3: Earnings management has a significant impact on stock market liquidity.

\section{METHODOLOGY}

The present study uses panel data of selected companies from 2010 to 2018, extracted from DataStream of the respective countries. Total 114 companies are from the manufacturing sector of Pakistan (25), India (30), Australia (30) and Singapore (29). The study uses different control variables (stock price, firm size, and volatility of the stock returns) which affect the stock liquidity, in the following model:

$$
\begin{aligned}
(I L L I Q) i, t=\beta_{0}+ & \beta_{1}(O C) i, t+\beta_{2}(I N S T) i, t \\
& +\beta_{3}(E M) i, t+\beta_{4}(S P) i, t \\
& +\beta_{5}(S Z) i, t+\beta_{6}(V O L) i, t+\varepsilon_{i, t}
\end{aligned}
$$

where, ILLIQ is stock market illiquidity, $\beta_{0}$ is constant, $O C$ is ownership concentration, INST is institutional ownership, EM is earnings management, $S P$ is stock price, $S$ is firm size, $V O L$ is volatility of stock returns, $\varepsilon$ is error term, $\beta_{1}$ to $\beta_{6}$ are slopes, $i$ represents the firm and $t$ indicates the time period.

We calculate the ownership concentration by the percentage to total stocks held by the top five stockholders. Many previous studies have followed the same approach to capture ownership concentration (Al-Rassas \& Kamardin, 2016; Al-Jaifi, 2017; Chalermchatvichien, Jumreornvong, Jiraporn, \& Singh, 2014). Institutional ownership is explained as the degree of equity in the firm held by institutional investors. Institutional investors include banks, mutual funds, financial and insurance companies. Institutional ownership (INST) is measured by dividing the number of stocks held by the institutional investors by the total stocks outstanding for firm i at the year t. Many of the prior researchers have used the same approach for measuring institutional ownership (De Cesari, Espenlaub, Khurshed, \& Simkovic, 2012; Rubin, 2007). 
We use discretionary accruals (DA) as a proxy for earnings management. We estimate DA by using the cross-sectional modified Jones (1991) model. For this purpose, separate industry-wide regressions are run to estimate the parameters of the following model:

$$
\begin{gathered}
\frac{T A C_{i t}}{T A S_{t-1}}=\alpha_{0}+\alpha_{1} \frac{1}{T A S_{t-1}}+\alpha_{2} \frac{\left(\Delta R E V_{i t}-\Delta R E C_{i t}\right)}{T A S_{t-1}} \\
+\alpha_{3} \frac{P P E_{i t}}{T A S_{t-1}}+\varepsilon_{t}
\end{gathered}
$$

where, $T A C_{i t}$ is the total accruals in year $t$ (calculated by subtracting cash flow from operations from net income); $T A S_{t-1}$ represents the total assets in year $t-1 ; \triangle R E V_{i t}$ is the change in revenue from year $t-1$ to year $t ; \quad \triangle R E C_{i t}$ is changing in receivables from year $t-1$ to year $t . P P E_{i t}$ in the equation denotes property, plant and equipment in a year; $\alpha, \alpha_{2}$ and $\alpha_{3}$ are estimated coefficients; $\alpha_{0}$ is constant and $\varepsilon$ is error term. Values of the coefficients $\alpha, \alpha$ and $\alpha$ are calculated by using the ordinary least square regression.

The non-discretionary accruals $\left(N D A_{i t}\right)$ for the sample firms are obtained by inserting the estimated parameters, in the above-mentioned equation by using the following formula:

$\frac{N D A_{i t}}{T A S_{t-1}}=\alpha_{0}+\alpha_{1} \frac{1}{T A S_{t-1}}+\alpha_{2} \frac{\left(\Delta R E V_{i t}-\Delta R E C_{i t}\right)}{T A S_{t-1}}+\alpha_{3} \frac{P P E_{i t}}{T A S_{t-1}}$

Discretionary accruals $\left(D A_{i t}\right)$ are then obtained as $D A_{i t}=T A C_{i t}-N D A_{i t}$

We use the absolute value of discretionary accruals as a proxy of earnings management, following Leuz, Nanda, and Wysocki (2003), Chung et al. (2009) and Al-Jaifi (2017).

Dependent variable stock liquidity refers to the extent to which stock can be traded in the market without altering its price (Umar \& Sun, 2016). We use Amihud's (2002) illiquidity measure (ILLIQ), defined as the ratio of the absolute stock return to the trading volume of the stock, to calculate its inverse the stock market liquidity. It is considered the best measure for capturing liquidity, and it has a strong theoretical appeal in the literature (Marcelo \& Quiros, 2006). According to Amihud (2002), ILLIQ is calculated by using the following formula:

$$
I L L I Q_{i y}=\frac{1}{D_{i y}} \sum_{t=o}^{D_{i y}} \frac{\left|R_{i y d}\right|}{V O L D_{i y d}}
$$

where, $I L L I Q_{i y}=$ Illiquidity for the stock of firm $i$ in year $y ; D_{i y}=$ Number of the days for the stock of firm $i$ in year $y$; $R_{\text {iyd }}=$ Stock return for the firm $i$ on day $d$ in year $y$; and $V O L D_{i y d}=$ Daily trading volume, higher value of ILLIQ depicts the lower stock liquidity and vice versa.

Control variable stock price is calculated by applying the same approach used by Riahi, Lamiri, and Arab (2013), Chung and Zhang (2011), and AlJaifi (2017). The stock price is calculated by taking reciprocal of the average daily closing price over the year, i.e., Price $=1 / \mu$ (Daily closing price). Firm size is measured by taking the natural logarithm of its total assets - following Pouraghajan, Tabari, Ramezani, Mansourinia, Emamgholipour, and Majd (2012), i.e., Size $=$ Ln (Total Assets). The volatility of the stock returns measures the risk associated with stock prices that arise due to an unfavorable event (Riahi et al., 2013). We calculate the volatility of stock returns by using the following formula: $V O L=\sigma$ (Returns). Table 1 summarizes the variables used in our study. It contains the description of all the variables and their proxies, with the references to

\begin{tabular}{|c|c|c|c|}
\hline Variables & Abbreviation & Proxies & References \\
\hline Illiquidity Measure & ILLIQ & $I L L I Q=\frac{1}{D_{i y}} \frac{\sum\left|R_{i y d}\right|}{V O L D_{i y d}}$ & $\begin{array}{l}\text { Marcelo \& Quiros (2006); Shin \& Kim } \\
\text { (2015); Al-Jaifi (2017). }\end{array}$ \\
\hline $\begin{array}{l}\text { Ownership } \\
\text { Concentration }\end{array}$ & $\mathrm{OC}$ & $\begin{array}{l}\text { Calculated by percentage to total } \\
\text { stocks outstanding held by the top five } \\
\text { stockholders. }\end{array}$ & $\begin{array}{l}\text { Al-Rassas \& Kamardin (2016); Al-Jaifi } \\
\text { (2017); Chalermchatvichien et al. (2014) }\end{array}$ \\
\hline $\begin{array}{l}\text { Institutional } \\
\text { Ownership }\end{array}$ & IO & $\begin{array}{c}\text { Number of stocks held by the } \\
\text { institutional investors/total stocks } \\
\text { outstanding }\end{array}$ & $\begin{array}{l}\text { Rubin (2007); Rehmwati De Cesari et al. } \\
(2012)\end{array}$ \\
\hline $\begin{array}{l}\text { Earnings } \\
\text { Management }\end{array}$ & EM & Modified Jones model 1991 & Al-Jaifi (2017) \\
\hline Stock Price & Price & Price $=\mu(1 /$ Daily closing price $)$ & Stoll (1978); Riahi et al. (2013) \\
\hline Firm Size & Size & Size $=\operatorname{Ln}($ Total Assets) & Pouraghajan et al. (2012); \\
\hline $\begin{array}{l}\text { Volatility of the } \\
\text { stock returns }\end{array}$ & VOL & $V O L=\sigma$ (Returns) & Jacoby \& Zheng (2010); Al-Jaifi (2017) \\
\hline
\end{tabular}
studies that have used these variables.

Table 1. Proxies of the study variables

\section{EMPIRICAL}

Table 2 sets out the descriptive statistics and correlation matrix. It sets out the mean, standard deviation and a correlation matrix to check the outlier and multicollinearity. The current study also applies the Generalized Method of Moments (GMM) to handle the issue of endogeneity as developed by Arellano and Bond (1991), Arellano and Bover (1995). González (2013) describes that the GMM model is used to deal with autoregressive properties of the dependent variable and to handle the endogeneity problem existing in dependent variables as well as unobserved firm related characteristics.

Outcomes of descriptive statistics reveal that ownership is highly concentrated in both developing and developed countries. Most of the shares are held by the top five owners of the companies. The average value of institutional ownership shows that although institutions buy shares of companies but their share is less than half of the total shares of the companies in this study. The high value of standard deviation suggests that there is a very large variation in the values of ownership concentration and 
institutional ownership. The standard deviation value of earnings management shows that there exists a large variation in the values of earning management, but overall there is generally a consistent pattern of earning management.

Table 2. Descriptive statistics and correlation matrix (overall)

\begin{tabular}{|c|c|c|c|c|c|c|c|c|c|}
\hline Variables & Mean & SD & ILLIQ & OC & IO & EM & SZ & PRICE & VOL \\
\hline ILLIQ & -5.801 & 6.453 & 1.000 & & & & & \\
\hline OC & 67.278 & 23.578 & 0.467 & 1.000 & & & & \\
\hline IO & 40.261 & 30.782 & -0.070 & -0.035 & 1.000 & & & \\
\hline EM & 1.243 & 1.507 & -0.745 & -0.364 & 0.064 & 1.000 & & \\
\hline SZ & 20.729 & 2.913 & 0.373 & 0.608 & -0.166 & -0.293 & 1.000 & \\
\hline PRICE & 4.952 & 16.054 & -0.087 & -0.402 & 0.012 & 0.129 & -0.430 & 1.000 & \\
\hline VOL & 0.007 & 0.005 & -0.074 & -0.157 & -0.134 & 0.007 & -0.253 & 0.172 & 1.000 \\
\hline
\end{tabular}

Note: $S D=$ Standard deviation, ILLIO = Illiquidity, $O C=$ Ownership Concentration, IO = Institutional Ownership, EM = Earning Management, $S Z=$ Size, PRICE = Stock Price, $V O L=$ Volatility of Stock Returns

Firm size measured as the natural log of total assets shows that there is more variation in the values of total assets. This indicates that companies invest in their total assets depending on the needs and available financial sources. This further explains that there is no consistency in the investment of total assets. Further, there is a large variation in share prices of the companies across developed and developing countries.

This is due to the different economic and business environment in developed and developing countries. Stock return volatility does not vary which means that stock returns volatility remains constant. From the correlation matrix, it is clear that correlation is weak among all the independent and control variables for all countries which indicate there is no issue of multicollinearity.

Table 3 represents the Variance Inflation Factor (VIF) test to verify the issue of multicollinearity. We find no issue of multicollinearity. To deal with endogeneity in the data, we apply the GMM technique because there is a chance of overlapping ownership concentration with institutional ownership.
Table 3. Test of Multicollinearity

\begin{tabular}{|c|c|c|}
\hline Variable & VIF & $\mathbf{1 / V I F}$ \\
\hline SZ & 2.32 & 0.430 \\
\hline OC & 2.21 & 0.453 \\
\hline PRICE & 1.27 & 0.789 \\
\hline EM & 1.16 & 0.859 \\
\hline VOL & 1.12 & 0.894 \\
\hline IO & 1.08 & 0.922 \\
\hline \multicolumn{2}{|l}{ Note: VIF is Variance Inflation Factor }
\end{tabular}

Overlapping can occur when institutional owners hold a large number of stocks so they fall in the categories of block holders at the same time. To avoid this problem and to get robust results, we run the model three times, first with all the study variables excluding institutional ownership in Model 1, while in the second time, ownership concentration is dropped in the Model 2 and in the third time all variables are regressed together in the Model 3 which is also an overall model. The results in Table 4 explain that ownership concentration has a significant effect on the ILLIQ in Model 3, whereas, Model 1 shows the insignificant effect of institutional ownership on ILLIQ.

Table 4. Two-step system dynamic panel regression estimation (overall)

\begin{tabular}{|c|c|c|c|}
\hline & Model 1 & Model 2 & Model 3 \\
\hline L1 & $\begin{array}{l}0.723^{* * * *} \\
(18.840)\end{array}$ & $\begin{array}{l}0.736^{* \ldots *} \\
(19.430)\end{array}$ & $\begin{array}{c}0.463^{* * * *} \\
(8.990) \\
\end{array}$ \\
\hline L2 & 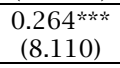 & $\begin{array}{c}0.251^{\text {* }} \text { (6.8* } \\
(6.880)\end{array}$ & 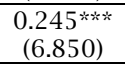 \\
\hline OC & --- & $\begin{array}{c}0.008 \\
(0.790) \\
\end{array}$ & $\begin{array}{c}0.036^{* * * *} \\
(5.850)\end{array}$ \\
\hline IO & $\begin{array}{c}0.010 \\
(1.490) \\
\end{array}$ & --- & $\begin{array}{c}0.043 * * * \\
(5.600)\end{array}$ \\
\hline EM & $\begin{array}{l}-0.151^{*} \\
(-1.860)\end{array}$ & $\begin{array}{l}-0.182^{* * *} \\
(-2.290)\end{array}$ & $\begin{array}{c}-0.284^{*} \text { * * * } \\
(-3.180)\end{array}$ \\
\hline SZ & $\begin{array}{c}-0.034 \\
(-0.440) \\
\end{array}$ & $\begin{array}{c}-0.034 \\
(-0.380) \\
\end{array}$ & $\begin{array}{c}-0.173^{* * * * *} \\
(-2.880)\end{array}$ \\
\hline Price & $\begin{array}{c}0.047^{* * * *} \\
(7.230)\end{array}$ & $\begin{array}{c}0.052^{* * * *} \\
(7.460)\end{array}$ & $\begin{array}{c}7.434 \\
(1.020)\end{array}$ \\
\hline VOL & $\begin{array}{c}34.346^{* *} \\
(2.420)\end{array}$ & $\begin{array}{c}35.164^{*} \\
(2.570)\end{array}$ & $\begin{array}{l}51.345^{*} \\
(1.960)\end{array}$ \\
\hline $\mathrm{C}$ & $\begin{array}{c}-0.194 \\
(-0.120)\end{array}$ & $\begin{array}{c}-0.277 \\
(-0.150) \\
\end{array}$ & $\begin{array}{c}-3.691 \\
(-2.800)\end{array}$ \\
\hline
\end{tabular}

Note: $L 1=$ First lag of dependent variable, L2 = Second lag of dependent variable, OC = Ownership Concentration, IO = Institutional Ownership, EM = Earning Management, $S Z=$ Size, PRICE = Stock Price, VOL=Volatility of Stock Returns, $C=C o n s t a n t ; * * * *$ $* *$, and $*$ represents significant level at $1 \%, 5 \%$, and $10 \%$.

These results show that ownership concentration is positively related to stock market liquidity. Ownership concentration increases stock liquidity. This increase in stock liquidity is due to active institutional investors like mutual funds or independent advisors having more information and more trading volume as compared to passive investors like insurance companies and banks trust departments. This ultimately puts a significant and positive effect on stock liquidity (Liu, 2013). However, in Model 1 where we take only ownership concentration as the independent variable and exclude institutional ownership, concentration has an insignificant impact on stock market liquidity. The reason for this relationship is that ownership of countries under study is mostly held by family 
members. However, family members who do not play any major role in the decisions and actions of a company and consequently the relationship between ownership concentration and stock market liquidity is insignificant.

We find institutional ownership has a significant and positive impact on stock market liquidity in Model 3. Institutional investors increase stock market liquidity due to having more inside information (Ali \& Hashmi, 2018). Institutional investors have more information as compared to other investors, their information quickly reflects in stock prices, which increases stock liquidity (Liu, 2013). This further signifies that institutional investors have better governance and can monitor the activities of managers and this characteristic indicates a positive signal to potential market participants thus liquidity is enhanced. Almutairi (2013), Rubin (2007), and Khorana et al. (2005) report the same findings. In addition, Almutairi (2013) explains that auditors prefer institutional investors because they can increase the reliability and quality of financial reporting. However, when we take institutional ownership alone as the independent variable and exclude ownership concentration, findings of our study reveal an insignificant effect because ownership of institutional investors is low as compared to concentrated ownership, as found by Boehmer and Kelley (2009). We ascertain that earnings management has a significant adverse impact on stock market liquidity. The reason for this negative relationship is that earnings management practices lead to decreasing the reliability of financial reports of the company. It also creates information asymmetry between inside and outside stockholders of the company which results in enhancing the uncertainty about the future cash flows of the company; all these factors discourage the stockholders from investing in the stock of the company, so the stock market liquidity decreases (Bar-Yosef \& Prencipe, 2013). We take firm size as a control variable. Outcomes of size reveal a significant and inverse impact on stock market liquidity in Model 3 only. Negative impact shows that smaller firms are able to control earnings and evade reporting losses in their financial reporting, while larger firms do not have this advantage because their information exposure to the stockholders is greater. We also take stock price as a control variable that has a significant positive impact on stock market liquidity. This is because a higher stock price gives the signal to the investor that a company's stock is performing well in the market. Amihud, Mendelson, and Lauterbach (1997) find the same results. The impact of stock return volatility on the stock market liquidity is significant and positive which shows that with an increase in stock return volatility, there is the increase in stock market liquidity due to chances of earning more returns. We find that all models provide mixed results but Model 3 predicts more significant results concerning all variables.

Table 5. Two-step system dynamic panel regression estimation (developing and developed countries)

\begin{tabular}{|c|c|c|c|c|c|c|}
\hline \multirow[t]{2}{*}{ Variables } & \multicolumn{3}{|c|}{ Developing Countries } & \multicolumn{3}{|c|}{ Developed Countries } \\
\hline & Model 1 & Model 2 & Model 3 & Model 1 & Model 2 & Model 3 \\
\hline L1 & $\begin{array}{l}0.663 \text { *** } \\
(21.310)\end{array}$ & $\begin{array}{l}0.663 \text { *** } \\
(17.720)\end{array}$ & $\begin{array}{l}0.656^{\text {**** }} \\
(19.130)\end{array}$ & $\begin{array}{l}0.746^{\text {*** }} \\
(36.800)\end{array}$ & $\begin{array}{l}0.752^{*} \text { 虾 } \\
(36.090)\end{array}$ & $\begin{array}{l}0.749 \text { 被 } \\
(37.330)\end{array}$ \\
\hline $\mathrm{L} 2$ & $\begin{array}{l}0.281^{\text {炏火 }} \\
(10.730)\end{array}$ & 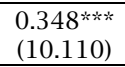 & 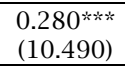 & $\begin{array}{c}0.190^{\text {**** }} \\
(7.690)\end{array}$ & $\begin{array}{c}0.191^{\text {* }} \text { (7.750) } \\
(7.750)\end{array}$ & 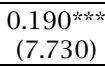 \\
\hline $\mathrm{OC}$ & $\begin{array}{l}0.041 \text { **** } \\
(14.330)\end{array}$ & --- & $\begin{array}{c}0.046^{* * * *} \\
(8.430)\end{array}$ & $\begin{array}{c}-0.001 \\
(-0.140)\end{array}$ & --- & $\begin{array}{c}0.001 \\
(0.230)\end{array}$ \\
\hline IO & --- & $\begin{array}{c}0.015^{* * *} \\
(3.810)\end{array}$ & $\begin{array}{c}-0.007 \\
(-0.880) \\
\end{array}$ & --- & $\begin{array}{c}-0.002 \\
(-0.390) \\
\end{array}$ & $\begin{array}{c}-0.002 \\
(-0.290) \\
\end{array}$ \\
\hline EM & $\begin{array}{c}-0.342^{*} * * * \\
(-5.240)\end{array}$ & $\begin{array}{c}-0.378^{* * * *} \\
(-5.000)\end{array}$ & $\begin{array}{c}-0.297^{*} * * \\
(-5.410)\end{array}$ & $\begin{array}{c}-0.027 \\
(-0.560) \\
\end{array}$ & $\begin{array}{c}-0.015 \\
(-0.300) \\
\end{array}$ & $\begin{array}{c}-0.025 \\
(-0.510) \\
\end{array}$ \\
\hline $\mathrm{SZ}$ & $\begin{array}{l}0.029 * \\
(1.810) \\
\end{array}$ & $\begin{array}{l}0.094^{* * *} \\
(2.290)\end{array}$ & $\begin{array}{l}0.044^{* * *} \\
(1.990)\end{array}$ & $\begin{array}{l}-0.106^{*} \\
(-1.690)\end{array}$ & $\begin{array}{c}-0.078 \\
(-1.380) \\
\end{array}$ & $\begin{array}{c}-00089 \\
(-1.550) \\
\end{array}$ \\
\hline Price & $\begin{array}{c}5.535^{* * * *} \\
(3.370)\end{array}$ & $\begin{array}{l}3.818^{*} \\
(1.750)\end{array}$ & $\begin{array}{l}4.098^{*} \\
(1.810)\end{array}$ & $\begin{array}{c}0.029 * \% * * \\
(7.690)\end{array}$ & $\begin{array}{c}0.030 * \% * \\
(8.120)\end{array}$ & 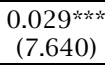 \\
\hline VOL & $\begin{array}{c}6.645 \\
(0.630) \\
\end{array}$ & $\begin{array}{l}13.472 \\
(1.240) \\
\end{array}$ & $\begin{array}{c}7.887 \\
(0.790) \\
\end{array}$ & $\begin{array}{c}7.935 \\
(0.950) \\
\end{array}$ & $\begin{array}{c}6.822 \\
(0.870) \\
\end{array}$ & $\begin{array}{c}7.429 \\
(0.930) \\
\end{array}$ \\
\hline $\mathrm{C}$ & $\begin{array}{c}-4.345 \\
(-10.590) \\
\end{array}$ & $\begin{array}{c}-2.500 * * * * \\
(-2.700)\end{array}$ & 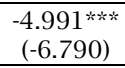 & $\begin{array}{c}1.509 \\
(1.260) \\
\end{array}$ & $\begin{array}{c}1.106 \\
(0.910) \\
\end{array}$ & $\begin{array}{c}1.254 \\
(0.990) \\
\end{array}$ \\
\hline
\end{tabular}

This study explains the analysis of developed and developing countries in Table 5 . Analysis reveals varying outcomes based on the nature of business and different economic conditions of each county. Ownership concentration in developing countries has a significant positive impact on stock return liquidity. This is because in developing countries, there is an increased number of concentrated owners like large individual investors and family owners, whereas institutional owners do not own a large amount of shares. May, Fah, and Hassan (2018) also document that developing countries are dominated by concentrated owners. Pakistani firms also have concentrated ownership with the dominance of family owners (Javeed \& Lefen, 2019). As a result, stock market liquidity increases because dominant concentrated owners increase trading of stocks to get more benefits. However, in developed countries, ownership concentration does not have any significant impact on stock market liquidity which confirms the finding of Comerton-Forde and Rydge (2006).

Institutional investors have generally an insignificant impact on stock market liquidity in both developing and developed countries. However, in Model 2, institutional ownership has a significant positive impact on stock market liquidity. Earnings management has a significant inverse impact on stock market liquidity which ensures that it leads to discouraging the reliance on financial reports of the firm which causes decreasing in the liquidity of the stock market. Negative impact is also due to the 
weak practices of corporate governance in developing countries which open rooms for the managers to manipulate financial outputs for their own benefits which creates liquidity issues. There is implementation of strong corporate governance practices and high stockholders' rights protection in developed countries. All of these factors add up to make the earnings management practices weaker, and insignificant in affecting stock market liquidity. According to Lin, Liu, and Noronha (2016), informative earnings management is advantageous for outside investors because they do not have direct access to the company's private information. The size has a significant positive impact on stock market liquidity in developing countries. The positive impact of size shows that larger the size of the firm is, the greater the stock market liquidity is. In addition, larger firms are generally older and more efficient than smaller firms (Lundvall \& Battese, 2000). These results are supported by the results of Al-Jaifi (2017), Chordia, Roll, and Subrahmanyam (2000). In case of developed countries, firm size has significant and negative impact on stock market liquidity in Model 1 only. Stock price shows a significant positive impact on stock market liquidity for developing and developed countries. This shows that when stock prices are increased, investors are more prone to invest in stocks in anticipation of capital gains. Stock return volatility is another control variable of our study which shows an insignificant impact on stock market liquidity for developed and developing countries.

We also use two step system dynamic panel regression for the analysis of individual countries in Table 6. The results show that ownership concentration is significantly negatively associated with stock market liquidity in Australia and Singapore. From these two countries, if the ownership concentration is high, then stock market liquidity will be low. This is because the proxy used for liquidity is reversed in this study, so all the relationships also go in opposite direction (Al-Jaifi, 2017; Marcelo \& Quiros, 2006; Shin \& Kim, 2015; Staglianò, 2018). This relationship exists because when the ownership concentration is high, the stock of the company is held by a few stockholders and not traded in the stock market, causing decreasing of the liquidity (Brockman \& Oslen, 2013). These results are supported by the studies conducted by Brockman and Oslen (2013), La Porta et al. (2002). In Pakistan, ownership concentration has a significant and positive impact on stock market liquidity. This signifies that in Pakistan, shares of firms are mostly owned by concentrated owners, thus they increase liquidity of stocks. However, in India, ownership concentration has an insignificant impact on stock market liquidity. The reason for this relationship is that India is an emerging economy and ownership is mostly held by family members. However, family members who do not play any major role in the decisions and actions of a company and consequently the relationship between ownership concentration and stock market liquidity is insignificant.

We find institutional ownership has a significant and negative impact on stock market liquidity for Singapore. This shows that in Singapore, institutional ownership leads to decreas stock market liquidity. In Pakistan, institutional ownership has significant positive impact on stock market liquidity. This finding shows that along with concentrated ownership, institutional ownership in Pakistan also helps to enhance liquidity of stock. We ascertain that earnings management has a significant adverse impact on stock market liquidity in Pakistan and Singapore. This is because it creates information asymmetry between inside and outside stockholders of the company which results in enhancing the uncertainty about the future cash flows of the company. It discourages the stockholders from investing in the stock of the company, so the stock market liquidity decreases (Bar-Yosef \& Prencipe, 2013). Moreover, in Pakistan, the corporate governance mechanism is not very strong; managers have an incentive to manipulate earnings to protect their self-interest which in turn creates the liquidity problem. Our results are aligned with the findings of Ascioglu et al. (2012), Chung et al. (2009), Bar-Yosef and Prencipe (2013) and AlJaifi (2017)

For India and Australia, the relationship between earnings management and stock market liquidity is generally insignificant. This signifies that investors in India are more reluctant to invest in those stocks whose prices tend to increase. Morse and Ushman (1983) also report the insignificant relationship between earnings management and stock market liquidity. In the Indian market, and emerging economy, the highly concentrated ownership keeps a check on managers more actively and does not give them the opportunity to indulge in earnings management practices (Cascino et al., 2010; Wang, 2006). However, in Australia, earnings management does not affect stock market liquidity. Australia is a developed country with a strong corporate governance mechanism, so earnings management practices are discouraged.

Firm size shows a significant negative impact on stock market liquidity in Pakistan and Australia, whereas, it reveals significant but negative impact on stock market liquidity in Singapore in all three models. These significant results are supported by the results of Chordia et al. (2000), Al-Jaifi (2017). Larger firms have easier access to finance and face lower levels of legal and corruption issues as compared to smaller firms (Beck, Demirgüç-Kunt, \& Maksimovic, 2005). In addition, larger firms are generally older and more efficient than smaller firms (Lundvall \& Battese, 2000). Whereas, in India the firm size has insignificant impact on the stock market liquidity.

The stock price is found insignificant for Pakistan in Model 3 but in Model 1 and Model 2, results are significant. This is because a higher stock price gives the signal to the investor that $a$ company's stock is performing well in the market. Amihud et al. (1997) find the same results. For India, the stock price has an insignificant impact on stock market liquidity. However, for Australia and Singapore, the stock price has a significant positive impact on the liquidity of the stock market in all three models which shows that investors are keener to invest in stocks with increasing prices. The impact of stock return volatility on the stock market liquidity is significant and positive in Australia and Singapore. Greater volatility attracts the investors hoping to earn more return. However, in Pakistan, stock return volatility shows a significant and positive impact on stock market liquidity in Model 3 only, whereas in India, it shows a significant and positive impact on stock market liquidity in Model 2. 
Table 6. Two step system dynamic panel regression estimation (separate analysis)

\begin{tabular}{|c|c|c|c|c|c|c|c|c|c|c|c|c|}
\hline \multirow{2}{*}{ Variables } & \multicolumn{3}{|c|}{ Pakistan } & \multicolumn{3}{|c|}{ India } & \multicolumn{3}{|c|}{ Australia } & \multicolumn{3}{|c|}{ Singapore } \\
\hline & Model 1 & Model 2 & Model 3 & Model 1 & Model 2 & Model 3 & Model 1 & Model 2 & Model 3 & Model 1 & Model 2 & Model 3 \\
\hline L1 & $\begin{array}{l}0.520^{* \ldots * * *} \\
(13.770)\end{array}$ & $\begin{array}{l}0.489^{* * * * *} \\
(12.080)\end{array}$ & $\begin{array}{c}0.463^{* * * *} \\
(8.990)\end{array}$ & $\begin{array}{l}-1.359^{* * k} \\
(-2.360)\end{array}$ & $\begin{array}{c}-0.230 \\
(-0.850)\end{array}$ & $\begin{array}{c}-1.359^{* * *} \\
(-2.370)\end{array}$ & $\begin{array}{c}0.282^{* * * *} \\
(8.600)\end{array}$ & $\begin{array}{c}0.300^{* * * *} \\
(7.780)\end{array}$ & $\begin{array}{c}0.283^{* \ldots * *} \\
(7.300)\end{array}$ & 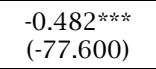 & 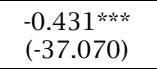 & 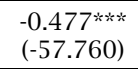 \\
\hline L2 & $\begin{array}{l}0.246^{* * * *} \\
(11.950)\end{array}$ & $\begin{array}{c}0.252^{* \ldots * *} \\
(7.600)\end{array}$ & $\begin{array}{c}0.245^{* * * *} \\
(6.850)\end{array}$ & $\begin{array}{c}-0.852^{* * * *} \\
(-2.680) \\
\end{array}$ & $\begin{array}{l}0.848^{* * *} \\
(2.510)\end{array}$ & $\begin{array}{c}-0.852^{* * * *} \\
(-2.690) \\
\end{array}$ & $\begin{array}{c}-0.091 * \\
(-1.960) \\
\end{array}$ & $\begin{array}{l}-0.079^{*} \\
(-1.850) \\
\end{array}$ & $\begin{array}{c}-0.093^{* * *} \\
(-2.160) \\
\end{array}$ & $\begin{array}{c}1.357^{* * * *} \\
(6.180)\end{array}$ & $\begin{array}{c}2.114^{* * * * *} \\
(5.350) \\
\end{array}$ & $\begin{array}{c}1.370 * * * * \\
(2.890)\end{array}$ \\
\hline $\mathrm{OC}$ & 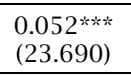 & & $\begin{array}{c}0.036^{* * * *} \\
(5.850)\end{array}$ & $\begin{array}{c}0.000 \\
(-0.290) \\
\end{array}$ & & $\begin{array}{c}0.000 \\
(-0.290) \\
\end{array}$ & $\begin{array}{l}-0.022^{* * *} \\
(-2.580) \\
\end{array}$ & & $\begin{array}{c}-0.025^{* * * * *} \\
(-3.380)\end{array}$ & $\begin{array}{c}-0.00001^{*} \text { * } \\
(-6.650)\end{array}$ & & $\begin{array}{c}-0.00001^{* * *} \\
(-2.400)\end{array}$ \\
\hline IO & & $\begin{array}{l}0.055^{* \ldots * * *} \\
(21.150)\end{array}$ & $\begin{array}{c}0.043^{* \ldots *} \\
(5.600)\end{array}$ & & $\begin{array}{c}0.000 \\
(0.310)\end{array}$ & $\begin{array}{l}0.000 \\
(0.050) \\
\end{array}$ & & $\begin{array}{c}-0.012 \\
(-1.050) \\
\end{array}$ & $\begin{array}{c}0.004 \\
(0.470) \\
\end{array}$ & & 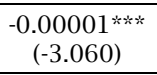 & $\begin{array}{c}-0.00001 * \\
(-1.760)\end{array}$ \\
\hline EM & $\begin{array}{c}-0.241^{\text {***** }} \\
(-4.340)\end{array}$ & $\begin{array}{c}-0.249^{* * * * * *} \\
(-2.600)\end{array}$ & 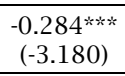 & $\begin{array}{c}0.000 \\
(-1.620) \\
\end{array}$ & $\begin{array}{c}-0.00002^{*} \\
(-1.700)\end{array}$ & $\begin{array}{c}0.000 \\
(-1.620) \\
\end{array}$ & $\begin{array}{c}0.052 \\
(1.450) \\
\end{array}$ & $\begin{array}{c}0.064 \\
(1.630) \\
\end{array}$ & $\begin{array}{c}0.052 \\
(1.410) \\
\end{array}$ & $\begin{array}{c}-0.0004^{* * * *} \\
(-6.630)\end{array}$ & $\begin{array}{c}-0.0004^{* * * *} \\
(-8.150)\end{array}$ & $\begin{array}{c}-0.0004^{* \cdots * * *} \\
(-6.520)\end{array}$ \\
\hline SZ & 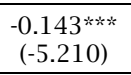 & 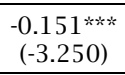 & 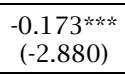 & $\begin{array}{c}0.000 \\
(-0.890) \\
\end{array}$ & $\begin{array}{c}0.000 \\
(1.250)\end{array}$ & $\begin{array}{c}0.000 \\
(-0.930)\end{array}$ & 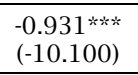 & 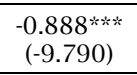 & 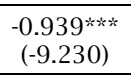 & $\begin{array}{c}0.0003^{*} \text { (25.190) } \\
\end{array}$ & 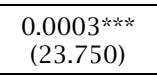 & $\begin{array}{c}0.0003^{*} \text { (13.570) } \\
\end{array}$ \\
\hline Price & $\begin{array}{c}8.352^{* * * * *} \\
(3.320)\end{array}$ & $\begin{array}{c}7.781^{* \ldots * *} \\
(2.460)\end{array}$ & $\begin{array}{c}7.434 \\
(1.020) \\
\end{array}$ & $\begin{array}{c}0.000 \\
(-0.470) \\
\end{array}$ & $\begin{array}{c}0.000 \\
(1.360) \\
\end{array}$ & $\begin{array}{c}0.000 \\
(-0.470) \\
\end{array}$ & $\begin{array}{l}0.040^{* * * * *} \\
(21.240)\end{array}$ & $\begin{array}{l}0.042^{* \ldots * *} \\
(22.860)\end{array}$ & $\begin{array}{l}0.040^{* * * *} \\
(19.630)\end{array}$ & $\begin{array}{c}0.00005^{* * * *} \\
(49.780)\end{array}$ & $\begin{array}{c}0.00004 * * * \\
(64.380)\end{array}$ & $\begin{array}{c}0.00005^{*} * * * * \\
(42.790)\end{array}$ \\
\hline VOL & $\begin{array}{c}7.924 \\
(0.230) \\
\end{array}$ & $\begin{array}{l}46.580 \\
(1.630) \\
\end{array}$ & $\begin{array}{l}51.345^{*} \\
(1.960)\end{array}$ & $\begin{array}{c}0.001 \\
(0.850) \\
\end{array}$ & $\begin{array}{c}0.005^{\text {* }}(3.020) \\
(3.0)\end{array}$ & $\begin{array}{c}0.001 \\
(0.860) \\
\end{array}$ & $\begin{array}{c}60.134^{*} \text { 秋 } \\
(6.700)\end{array}$ & $\begin{array}{c}60.541^{\text {* }}(8.810) \\
(8.4\end{array}$ & 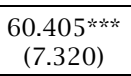 & $\begin{array}{c}0.011^{* \ldots * *} \\
(2.770)\end{array}$ & $\begin{array}{c}0.013^{* \ldots *} \\
(4.590)\end{array}$ & $\begin{array}{l}0.009^{* *} \\
(2.330)\end{array}$ \\
\hline C & 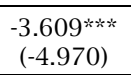 & $\begin{array}{l}-1.689^{*} \\
(-1.760) \\
\end{array}$ & $\begin{array}{c}-3.691 \text { * } \\
(-2.800)\end{array}$ & $\begin{array}{c}0.000 \\
(0.640)\end{array}$ & $\begin{array}{c}-0.0001 * \\
(-1.650)\end{array}$ & $\begin{array}{c}0.000 \\
(0.650)\end{array}$ & 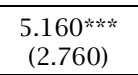 & 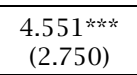 & $\begin{array}{c}5.192^{* \ldots *} \\
(2.820)\end{array}$ & 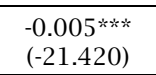 & $\begin{array}{l}-0.005^{* \ldots * *} \\
(-20.470)\end{array}$ & 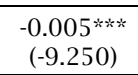 \\
\hline
\end{tabular}




\section{CONCLUSION}

The implementation of corporate governance policies is relatively weak in the emerging markets, and result in reducing the liquidity of stock markets. Consequently, we analyze how the ownership concentration, institutional ownership, and earnings management in developed and emerging countries influence stock market liquidity. We examine 114 listed companies from manufacturing sectors in Pakistan, India, Australia, and Singapore over the years 2010 to 2018. Previous studies have mainly focused on the New York Stock Exchange and the countries included in this study are neglected in the literature. Furthermore, all the variables used in our research model have not previously been jointly studied. Our analysis provides mixed results based on corporate governance rules and practices within companies of developed and developing countries; there is no consistency of results for the developed or emerging economies.

The significant and positive impact of ownership concentration on stock market liquidity in Model 3 of overall analysis suggests that concentrated owners have more power and incentive to ensure the liquidity of the stock market. Further, in Model 3, we find institutional ownership has a significant positive impact on the stock market liquidity that is in favor of signaling theory as institutional owners can monitor the managers in a firm.

Further, the study finds that earnings management negatively affects the stock market liquidity, it means earnings management practices lead to a decrease in the reliability of financial reports of a company. It also creates information asymmetry between inside and outside stockholders of the company which results in enhancing the uncertainty about the future cash flows. These factors discourage the stockholders to invest in the stock of the company due to which stock market liquidity decreases. The signaling theory supports these results according to which information reveals in the financial reports serves as a signal of the future financial position of the company.

The present study also incorporates analysis of developed and developing countries to evaluate the outputs of ownership and earnings management on stock market liquidity. Outputs reveal that these identified factors significantly affect stock market liquidity in developing countries but for developed countries, they have insignificant results. This is due to the reason that in developed countries, there is a robust corporate governance mechanism and blockholders cannot use private information to infringe on the rights of other stockholders. Moreover, in developed countries, strong practices of corporate governance do not allow managers to indulge in manipulating financial records which is the reason of the insignificant impact of earnings management on stock market liquidity. Companies in developing countries have also started following corporate governance practices which discourage management to involve in the manipulation of earnings. In addition to the overall and separate analysis of developed and developing countries, the present study evaluates the results based on the individual country analysis. Findings reveal that individual country differences exist, that appear to relate to the business and economic environment of that particular country.

Based on findings, we recommend that the regulators of the stock market protect the rights of all stockholders equally. They need to ensure that there are no infringements on the rights of minority stockholders. We suggest that future research should examine ownership structure in more depth with the other types of owners such as managerial and government, within other industry groups, and across more emerging economies. In light of the results of our study, the company policymakers could gain a clear idea of what type of ownership could enhance the liquidity of their stock in the market. We suggest ownership concentration and institutional ownership lead to increasing stock market liquidity. Therefore, firm directors should put their efforts to attract more concentrated and institutional stockholders. We focus on concentrated and institutional ownership, however, family ownership, public ownership, private ownership or foreign ownership along with other dimensions of corporate governance such as a board of directors, CEO duality may be a good future study. We cover two developing and two developed countries, more countries may be considered for a comprehensive analysis.

\section{REFERENCES}

1. Ajina, A., \& Habib, A. (2017). Examining the relationship between earning management and market liquidity. Research in International Business and Finance, 42, 1164-1172. https://doi.org/ 10.1016/j.ribaf.2017.07.054

2. Ali, M. S., \& Hashmi, S. H. (2018). Impact of institutional ownership on stock liquidity: Evidence from Karachi Stock Exchange, Pakistan. Global Business Review, 19(4), 939-951. https://doi.org/10.1177/0972150918772927

3. Al-Jaifi, H. (2017). Ownership concentration, earnings management and stock market liquidity: Evidence from Malaysia. Corporate Governance, 17(3), 490-510. https://doi.org/10.1108/CG-06-2016-0139

4. Almutairi, A. (2013). The impact of institutional ownership and corporate debt on audit quality. Journal of Economic and Administrative Sciences, 29(2), 134-152. https://doi.org/10.1108/JEAS-09-2013-0031

5. Al-Rassas, A. H., \& Kamardin, H. (2016). Earnings quality and audit attributes in high concentrated ownership market. Corporate Governance, 16(2), 377-399. https://doi.org/10.1108/CG-08-2015-0110

6. Amihud, Y. (2002). Illiquidity and stock returns: cross-section and time-series effects. Journal of Financial Markets, 5(1), 31-56. https://doi.org/10.1016/S1386-4181(01)00024-6

7. Amihud, Y., Mendelson, H., \& Lauterbach, B. (1997). Market microstructure and securities values: Evidence from the Tel Aviv Stock Exchange. Journal of Financial Economics, 45(3), 365-390. https://doi.org/10.1016/S0304405X(97)00021-4

8. Arellano, M., \& Bond, S. (1991). Some tests of specification for panel data: Monte Carlo evidence and an application to employment equations. The Review of Economic Studies, 58(2), 277-297. https://doi.org/10.2307/2297968

9. Arellano, M., \& Bover, O. (1995). Another look at the instrumental variable estimation of error-components models. Journal of Econometrics, 68(1), 29-51. https://doi.org/10.1016/0304-4076(94)01642-D

10. Ascioglu, A., Hegde, S. P., Krishnan, G. V., \& McDermott, J. B. (2012). Earnings management and market liquidity. Review of Quantitative Finance and Accounting, 38(2), 257-274. https://doi.org/10.1007/s11156-0100225-9 
11. Bar-Yosef, S., \& Prencipe, A. (2013). The impact of corporate governance and earnings management on stock market liquidity in a highly-concentrated ownership capital market. Journal of Accounting, Auditing \& Finance, 28(3), 292-316. https://doi.org/10.1177/0148558X13492591

12. Beck, T., Demirgüç-Kunt, A., \& Maksimovic, V. (2005). Financial and legal constraints to growth: does firm size matter? The Journal of Finance, 60(1), 137-177. https://doi.org/10.1111/j.1540-6261.2005.00727.x

13. Bhide, A. (1994). Efficient markets, deficient governance. Harvard Business Review, 72(6), 128-140. Retrieved from https://hbr.org/1994/11/efficient-markets-deficient-governance

14. Block, J. H. (2011). How to pay nonfamily managers in large family firms: A principal-agent model. Family Business Review, 24(1), 9-27. https://doi.org/10.1177/0894486510394359

15. Boehmer, E., \& Kelley, E. K. (2009). Institutional investors and the informational efficiency of prices. The Review of Financial Studies, 22(9), 3563-3594. https://doi.org/10.1093/rfs/hhp028

16. Brennan, M. J., Chordia, T., \& Subrahmanyam, A. (1998). Alternative factor specifications, security characteristics, and the cross-section of expected stock returns. Journal of Financial Economics, 49(3), 345-373. https://doi.org/10.1016/S0304-405X(98)00028-2

17. Brockman, P., \& Olsen, B. C. (2013). Warrants, ownership concentration, and market liquidity. Managerial Finance, 39(4), 322-341. https://doi.org/10.1108/03074351311306157

18. Cascino, S., Pugliese, A., Mussolino, D., \& Sansone, C. (2010). The influence of family ownership on the quality of accounting information. Family Business Review, 23(3), 246-265. https://doi.org/10.1177/0894486510374302

19. Chalermchatvichien, P., Jumreornvong, S., Jiraporn, P., \& Singh, M. (2014). The effect of bank ownership concentration on capital adequacy, liquidity, and capital stability. Journal of Financial Services Research, 45(2), 219-240. https://doi.org/10.1007/s10693-013-0160-8

20. Chordia, T., Roll, R., \& Subrahmanyam, A. (2000). Commonality in liquidity. Journal of Financial Economics, 56(1), 3-28. https://doi.org/10.1016/S0304-405X(99)00057-4

21. Chung, H., Sheu, H. J., \& Wang, J. L. (2009). Do firms' earnings management practices affect their equity liquidity? Finance Research Letters, 6(3), 152-158. https://doi.org/10.1016/j.frl.2009.03.003

22. Chung, K. H., \& Zhang, H. (2011). Corporate governance and institutional ownership. Journal of Financial and Quantitative Analysis, 46(1), 247-273. https://doi.org/10.1017/S0022109010000682

23. Claessens, S., \& Yurtoglu, B. B. (2013). Corporate governance in emerging markets: A survey. Emerging Markets Review, 15, 1-33. https://doi.org/10.1016/j.ememar.2012.03.002

24. Coffee, J. C. (1991). Liquidity versus control: The institutional investor as corporate monitor. Columbia Law Review, 91(6), 1277-1368. https://doi.org/10.2307/1123064

25. Comerton-Forde, C., \& Rydge, J. (2006). The current state of Asia-Pacific stock exchanges: A critical review of market design. Pacific-Basin Finance Journal, 14(1), 1-32. https://doi.org/10.1016/j.pacfin.2005.05.002

26. Connelly, J. T., Limpaphayom, P., \& Nagarajan, N. J. (2012). Form versus substance: The effect of ownership structure and corporate governance on firm value in Thailand. Journal of Banking \& Finance, 36(6), 1722-1743. https://doi.org/10.1016/j.jbankfin.2012.01.017

27. Dang, T. L., Nguyen, T. H., Tran, N. T. A., \& Vo, T. T. A. (2018). Institutional ownership and stock liquidity: International evidence. Asia-Pacific Journal of Financial Studies, 47(1), 21-53. https://doi.org/ $10.1111 /$ ajfs.12202

28. De Cesari, A., Espenlaub, S., Khurshed, A., \& Simkovic, M. (2012). The effects of ownership and stock liquidity on the timing of repurchase transactions. Journal of Corporate Finance, 18(5), 1023-1050. https://doi.org/10.1016/j.jcorpfin.2012.06.004

29. Desai, H., Rajgopal, S., \& Venkatachalam, M. (2004). Value-glamour and accruals mispricing: One anomaly or two? The Accounting Review, 79(2), 355-385. https://doi.org/10.2308/accr.2004.79.2.355

30. Desoky, A. M., \& Mousa, G. A. (2013). An empirical investigation of the influence of ownership concentration and identity on firm performance of Egyptian listed companies. Journal of Accounting in Emerging Economies, 3(2), 164-188. https://doi.org/10.1108/20421161311320698

31. Dyck, A., Lins, K. V., Roth, L., \& Wagner, H. F. (2019). Do institutional investors drive corporate social responsibility? International evidence. Journal of Financial Economics, 131(3), 693-714. https://doi.org/10.1016/j.jfineco.2018.08.013

32. Goh, Q. R., Annuar, M. N., \& Zariyawati, M. A. (2014). The benefits of diversification in Asean stock market to Malaysia investors. Asian Social Science, 10(4), 78-92. https://doi.org/10.5539/ass.v10n4p78

33. González, V. M. (2013). Leverage and corporate performance: International evidence. International Review of Economics \& Finance, 25, 169-184. https://doi.org/10.1016/j.iref.2012.07.005

34. Grossman, S. J., \& Hart, O. D. (1988). One share-one vote and the market for corporate control. Journal of Financial Economics, 20, 175-202. https://doi.org/10.1016/0304-405X(88)90044-X

35. Jacoby, G., \& Zheng, S. X. (2010). Ownership dispersion and market liquidity. International Review of Financial Analysis, 19(2), 81-88. https://doi.org/10.1016/j.irfa.2010.01.008

36. Javeed, S., \& Lefen, L. (2019). An analysis of corporate social responsibility and firm performance with moderating effects of CEO power and ownership structure: A case study of the manufacturing sector of Pakistan. Sustainability, 11(1), 248. https://doi.org/10.3390/su11010248

37. Javid, A. Y., \& Iqbal, R. (2008). Ownership concentration, corporate governance and firm performance: Evidence from Pakistan. The Pakistan Development Review, 47(4), 643-659. https://doi.org/10.30541/v47i4IIpp.643-659

38. Jiraporn, P., Miller, G. A., Yoon, S. S., \& Kim, Y. S. (2008). Is earnings management opportunistic or beneficial? An agency theory perspective. International Review of Financial Analysis, 17(3), 622-634. https://doi.org/ 10.1016/j.irfa.2006.10.005

39. Jones, J. J. (1991). Earnings management during import relief investigations. Journal of Accounting Research, 29(2), 193-228. https://doi.org/10.2307/2491047

40. Khorana, A., Servaes, H., \& Tufano, P. (2005). Explaining the size of the mutual fund industry around the world. Journal of Financial Economics, 78(1), 145-185. https://doi.org/10.1016/j.jfineco.2004.08.006

41. La Porta, R., Lopez-de-Silanes, F., Shleifer, A., \& Vishny, R. (2002). Investor protection and corporate valuation. The Journal of Finance, 57(3), 1147-1170. https://doi.org/10.1111/1540-6261.00457

42. Leano, M., \& Pedraza, A. (2018). Ownership concentration and market liquidity: Evidence from a natural experiment. Economics Letters, 167, 56-59. https://doi.org/10.1016/j.econlet.2018.02.024

43. Lei, Q., Lin, B., \& Wei, M. (2013). Types of agency cost, corporate governance and liquidity. Journal of Accounting and Public Policy, 32(3), 147-172. https://doi.org/10.1016/j.jaccpubpol.2013.02.008

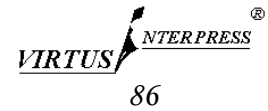


44. Leuz, C., Nanda, D., \& Wysocki, P. D. (2003). Earnings management and investor protection: An international comparison. Journal of Financial Economics, 69(3), 505-527. https://doi.org/10.1016/S0304-405X(03)00121-1

45. Lev, B. (1988). Toward a theory of equitable and efficient accounting policy. Accounting Review, 63(1), 1-22.

46. Lin, Z., Liu, M., \& Noronha, C. (2016). The Impact of Corporate Governance on Informative Earnings Management in the Chinese Market. Abacus, 52(3), 568-609. https://doi.org/10.1111/abac.12084

47. Liu, S. (2013). Institutional ownership and stock liquidity. Investment Management and Financial Innovations, 10(4), 18-26. Retrieved from https://businessperspectives.org/images/pdf/applications/publishing/ templates/article/assets/5492/imfi_en_2013_04_Liu.pdf

48. Lundvall, K., \& Battese, G. E. (2000). Firm size, age and efficiency: evidence from Kenyan manufacturing firms. The Journal of Development Studies, 36(3), 146-163. https://doi.org/10.1080/00220380008422632

49. Marcelo, J. L. M., \& Quirós, M. D. M. M. (2006). The role of an illiquidity risk factor in asset pricing: Empirical evidence from the Spanish stock market. The Quarterly Review of Economics and Finance, 46(2), 254-267. https://doi.org/10.1016/j.qref.2005.08.002

50. Maug, E. (1998). Large shareholders as monitors: Is there a trade-off between liquidity and control? The Journal of Finance, 53(1), 65-98. https://doi.org/10.1111/0022-1082.35053

51. May, T. Y., Fah, C. F., \& Hassan, T. (2018). Impacts of ownership concentration and liquidity on stock momentum profitability in Malaysia. Asian Academy of Management Journal of Accounting \& Finance, 14(1), 57-81. https://doi.org/10.21315/aamjaf2018.14.1.3

52. Mehmood, R., Hunjra, A. I., \& Chani, M. I. (2019). The impact of corporate diversification and financial structure on firm performance: Evidence from South Asian countries. Journal of Risk and Financial Management, 12(1), 1-17. https://doi.org/10.3390/jrfm12010049

53. Morse, D., \& Ushman, N. (1983). The effect of information announcements on the market microstructure. Accounting Review, 58(2), 247-258.

54. Mostafa, W. (2017). The impact of earnings management on the value relevance of earnings: Empirical evidence from Egypt. Managerial Auditing Journal, 32(1), 50-74. https://doi.org/10.1108/MAJ-01-2016-1304

55. Pouraghajan, A., Tabari, N. A. Y., Ramezani, A., Mansourinia, E., Emamgholipour, M., \& Majd, P. (2012). Relationship between cost of capital and accounting criteria of corporate performance evaluation: Evidence from Tehran Stock Exchange. World Applied Sciences Journal, 20(5), 666-673. Retrieved from https://pdfs.semanticscholar.org/4f20/5114747b48c1fd3eccb19a2199d6f9e562c4.pdf

56. Riahi, Y., Lamiri, I., \& Arab, M. B. (2013). The impact of earnings management on liquidity: Case of the Tunisian Stock Market. Journal of Finance \& Economics, 1(4), 10-29. https://doi.org/10.12735/jfe.v1i4p10

57. Rubin, A. (2007). Ownership level, ownership concentration and liquidity. Journal of Financial Markets, 10(3), 219-248. https://doi.org/10.1016/j.finmar.2007.04.002

58. Saleh, A. S., Halili, E., Zeitun, R., \& Salim, R. (2017). Global financial crisis, ownership structure and firm financial performance: An examination of listed firms in Australia. Studies in Economics and Finance, 34(4), 447-465. https://doi.org/10.1108/SEF-09-2016-0223

59. Sharif, F. A., Bino, A., \& Tayeh, M. (2015). The impact of ownership structure on stock liquidity: Evidence from Amman Stock Exchange. Jordan Journal of Business Administration, 11(1), 239-251. https://doi.org/10.35516/0338-011-001-010

60. Shin, D., \& Kim, B. (2015). Liquidity and credit risk before and after the global financial crisis: Evidence from the Korean corporate bond market. Pacific-Basin Finance Journal, 33, 38-61. https://doi.org/ 10.1016/j.pacfin.2015.03.003

61. Shleifer, A., \& Vishny, R. W. (1997). A survey of corporate governance. The Journal of Finance, 52(2), 737-783. https://doi.org/10.1111/j.1540-6261.1997.tb04820.x

62. Staglianò, R., La Rocca, M., \& Gerace, D. (2018). The impact of ownership concentration and analyst coverage on market liquidity: Comparative evidence from an auction and a specialist market. Economic Modelling, 70, 203214. https://doi.org/10.1016/j.econmod.2017.11.004

63. Stoll, H. R. (1978). The pricing of security dealer services: An empirical study of NASDAQ stocks. The Journal of Finance, 33(4), 1153-1172. https://doi.org/10.1111/j.1540-6261.1978.tb02054.x

64. Ullah, M., Afgan, N., Hashim, M., \& Khan, M. A. (2016). The impact of corporate governance on financial performance of Pakistan's cement manufacturing firms. City University Research Journal, 14-20. Retrieved from http://www.cityuniversity.edu.pk/curj/Journals/Journal/special_aic_16/2.pdf

65. Umar, M., \& Sun, G. (2016). Bank leverage and stock liquidity: Evidence from BRICS countries. Journal of Financial Economic Policy, 8(3), 298-315. https://doi.org/10.1108/JFEP-07-2015-0040

66. Wang, D. (2006). Founding family ownership and earnings quality. Journal of Accounting Research, 44(3), 619656. https://doi.org/10.1111/j.1475-679X.2006.00213.x

67. Wang, J. (2013). Liquidity commonality among Asian equity markets. Pacific-Basin Finance Journal, 21(1), 12091231. https://doi.org/10.1016/j.pacfin.2012.06.003

68. Yaghoobnezhad, A., Roodposhti, R. F., \& Zabihi, A. (2011). The study of relationship between institutional ownership and stock liquidity in Tehran stock exchange. Journal of Basic and Applied Scientific Research, 12(1), 2736-2742. Retrieved from https://pdfs.semanticscholar.org/e06b/4c520b19efd6e18c840aab2011011cb4ea6f.pdf

69. Yasser, Q. R., \& Mamun, A. A. (2017). The impact of ownership concentration on firm performance: Evidence from an emerging market. Emerging Economy Studies, 3(1), 34-53. https://doi.org/ $10.1177 / 2394901517696647$

70. Yoon, S. S., Miller, G., \& Jiraporn, P. (2006). Earnings management vehicles for Korean firms. Journal of International Financial Management \& Accounting, 17(2), 85-109. https://doi.org/10.1111/j.1467646X.2006.00122.X

71. Yosra, G., \& Sioud, O. B. O. (2011). Ultimate ownership structure and stock liquidity: Empirical evidence from Tunisia. Studies in Economics and Finance, 28(4), 282-300. https://doi.org/10.1108/10867371111171546 